\title{
Influence of the composition and the structure of different media on the release of aroma compounds
}

\author{
Anne-Marie SEUVRE ${ }^{\mathrm{a}, \mathrm{b}}$, Marian de los Angeles ESPINOSA DIAZ ${ }^{\mathrm{a}}$, \\ Philippe CAYOT ${ }^{\mathrm{a}}$, Andrée VOILLEY ${ }^{\mathrm{a} *}$ \\ a École Nationale de Biologie Appliquée à la Nutrition et à l'Alimentation, Université de Bourgogne, \\ 1 esplanade Erasme, 21000 Dijon, France \\ b IUT Génie Biologique, Bd. Dr Petitjean, BP 17867, 21078 Dijon Cedex, France
}

Received 4 July 2003 - Accepted 22 October 2003

Published online 26 March 2004

\begin{abstract}
The release of 2-nonanone and hexenol (hex-4-en-3-ol) was studied in model media with different structures and compositions: water, a gel of $\beta$-lactoglobulin, gelified or non-gelified emulsions (5.0\% Miglyol, 6.9\% $\beta$-lactoglobulin; the gelation was realized by heating) and milk. The aroma compounds were analyzed by gas chromatography. A strong influence of the nature of the volatile compound on its behavior towards the food matrix was observed: in the case of 2-nonanone, a hydrophobic compound $(\log \mathrm{P}=2.9)$ with a relatively high vapor-water partition coefficient $\left(\mathrm{K}_{\mathrm{mol}}=33.6\right)$, the release was greatly influenced by the composition and the structure of the medium. However, for hex-4-en-3-ol, a more hydrophilic compound $(\log \mathrm{P}=1.7)$ with a weaker vapor-water partition coefficient $\left(\mathrm{K}_{\mathrm{mol}}=0.5\right)$, the kinetics of the release of this compound were not influenced either by the composition or the structure of the matrix. The differences between the behavior of these two compounds in relation to the composition and the structure of the matrix indicated that the release of aroma was principally influenced by the interactions with the non-volatile constituents of the medium, $\beta$-lactoglobulin and Miglyol. The role of structure was shown by the comparison of the release of 2-nonanone in a gel to its release in a gel of the same composition that had been destructurated. However, this effect was less important than that of the composition of the food matrix.
\end{abstract}

\section{Structure of media / $\beta$-lactoglobulin / retention / release / aroma compound}

Résumé - Influence de la composition et de la structure de différents milieux sur la libération de composés d'arôme. La libération de la 2-nonanone et de l'hexenol (hex-4-en-3-ol) a été étudiée en milieux modèles de différentes structures et composition : eau, gel de $\beta$-lactoglobuline, émulsions (5,0\% Miglyol, 6,9\% $\beta$-lactoglobuline) gélifiées (gel réalisé par chauffage) ou non, lait. Une très grande influence de la nature du composé volatil sur son comportement vis-à-vis de la matrice alimentaire a été observée : dans le cas de la 2-nonanone, composé hydrophobe $(\log \mathrm{P}=2,9)$ avec un coefficient de partage vapeur-eau relativement élevé $\left(\mathrm{K}_{\mathrm{mol}}=33,6\right)$, la libération est largement influencée par la composition et la structure du milieu. Cependant, pour le hex-4-en-3-ol, composé plus hydrophile $(\log \mathrm{P}=1,7)$ ayant un plus faible coefficient de partage vapeur-eau $\left(\mathrm{K}_{\text {mol }}=0,5\right)$, les cinétiques de libération de ce composé ne sont pas influencées par la composition et la structure de la matrice. La différence de comportement de ces deux composés vis-à-vis de la composition et de la structure de la matrice indique que la libération des arômes est principalement influencée par les

\footnotetext{
* Corresponding author: voilley@u-bourgogne.fr
} 
interactions avec les constituants non volatils du milieu, $\beta$-lactoglobuline et Miglyol. Le rôle de la structure est montré en comparant la libération de la 2-nonanone dans un gel à celle dans un gel de même composition mais préalablement déstructuré. Cet effet reste cependant moins important que celui de la composition de la matrice alimentaire pour ce composé.

Structure du milieu / $\beta$-lactoglobuline / rétention / libération / composé d'arôme

\section{INTRODUCTION}

Foods are complex media where all ingredients can interact with each other. The interactions between flavor compounds and food ingredients and their influence on flavor perception have a predominant role in their acceptance by consumers (Guichard [9]). The release of these aroma compounds is conditioned by numerous parameters. Lipids play an important role in the behavior of the aroma compounds. With a reduced fat product, considerable changes happen and a new formulation becomes necessary using molecules able to trap aroma molecules such as proteins. $\beta$-lactoglobulin was selected as model to study the interactions between aroma molecules and protein. $\beta$-lactoglobulin is the predominant globular protein in whey. This protein has interesting functional properties used for texturisation and the control of syneresis in some products, such as delicatessen ice cream. The interactions between the aroma compounds and the $\beta$-lactoglobulin depend on the conformational state of the protein, temperature, $\mathrm{pH}$ [13], the presence of other molecules (salts, lactose and lipids) [20, 28] and the different chemical classes of the aroma compounds [24]. Recently, Jameson et al. [12] studied the flexibility and the functionality of bovine $\beta$-lactoglobulin and showed the importance of the hydrophobic pocket into which a variety of hydrophobic molecules could bind. When the protein is in an "oil-in-water" emulsion [29] it forms an interfacial membrane which prevents flocculation, coalescence and creaming of the system. Electrostatic repulsions and/or steric hindrance at the interface stabilize the emulsion [1, 14]. During the absorption at an interface, the globular proteins partially keep their secondary and tertiary structures. Shimizu [27] has shown that the conformational changes of $\beta$-lactoglobulin at the interface concern only one part of the protein: the $\alpha$ helix would remain non-denatured [29]. During adsorption at the oil-water interface, the $\beta$-lactoglobulin becomes partially unfolded [18]. The important change in the structure of $\beta$-lactoglobulin at the interface could have an effect on interactions with aroma compounds.

$\beta$-lactoglobulin aggregates after heatinduced denaturation, leading to either the formation of large linear aggregates or to small primary aggregates [5]. The heating of $\beta$-lactoglobulin solution (12\% protein, $90{ }^{\circ} \mathrm{C}$ for $60 \mathrm{~min}$ ) induces the formation of an opaque and rigid gel, between $\mathrm{pH} 4$ and 6 , and transparent and elastic gels above and under this $\mathrm{pH}$ interval [15]. For a heating time of $15 \mathrm{~min}$ the hardness of the $\beta$-lactoglobulin gel increases with the heating temperature, and at $90{ }^{\circ} \mathrm{C}$ the hardness increases with the time of heating [17]. Consequently, the $\beta$-lactoglobulin denaturation during gelation depends on the medium conditions which could modify the $\beta$-lactoglobulin-aroma compound interactions.

In order to understand the release of aroma from complex media better, it is necessary to take into account the rheological properties of the food matrix. In fact, the interactions between proteins can modify the affinity of aroma compounds for the matrix. It induces changes in the nature and the number of fixation sites for the aroma molecules. Several authors have observed that the increase in the viscosity of the medium induced a decrease in the release 
Table I. Physicochemical and sensorial characteristics of the aroma compounds.

\begin{tabular}{|c|c|c|}
\hline & 2-nonanone & Hex-4-en-3-ol \\
\hline Molecular formula & & \\
\hline Odor descriptor ${ }^{\mathrm{a}}$ & Rose, tea & Grass \\
\hline Molecular weight $\left(\mathrm{g} \cdot \mathrm{mol}^{-1}\right)$ & 142 & 100 \\
\hline Densitya & $0.832\left(\right.$ at $\left.25^{\circ} \mathrm{C}\right)$ & 0.851 (at $15^{\circ} \mathrm{C}$ ) \\
\hline Boiling point ${ }^{\mathrm{a}}\left({ }^{\circ} \mathrm{C}\right)$ & 195 & 156 \\
\hline Purity $(\%)$ & 99.9 & 98.0 \\
\hline $\begin{array}{l}\text { Saturated vapor pressure } \\
\mathrm{P}_{\mathrm{i}}^{\mathrm{s}}(\mathrm{Pa}) \text { at } 25^{\circ} \mathrm{C}\end{array}$ & 65 & 133 \\
\hline Hydrophobicity ${ }^{d} \log P$ & 2.9 & 1.7 \\
\hline Water solubility ${ }^{\mathrm{b}}$ at $25^{\circ} \mathrm{C}\left(\mathrm{g} \cdot \mathrm{L}^{-1}\right)$ & 0.4 & 18.0 \\
\hline $\begin{array}{l}\text { Molar partition coefficient }{ }^{\mathrm{b}}\left(\mathrm{K}_{\mathrm{mol}}\right) \\
\text { at } 25^{\circ} \mathrm{C} \text { in water }\end{array}$ & 33.6 & 0.5 \\
\hline $\begin{array}{l}\text { Mass partition coefficient }{ }^{\mathrm{b}}\left(\mathrm{K}_{\text {mass }}\right) \\
\text { at } 25^{\circ} \mathrm{C} \text { in water }\end{array}$ & 17.9 & 0.3 \\
\hline
\end{tabular}

${ }^{a}$ Furia and Bellanca [8]; ${ }^{b}$ experimental values, Espinosa Diaz [6]; ${ }^{c}$ estimated values with the GomezThodos method [7]; ${ }^{\mathrm{d}}$ estimated values with the Rekker's method [6].

of the aroma and in the perceived intensity $[16,30]$. Rankin and Bodyfelt [23] have shown, by studying the release of diacetyle in guar gum, xanthan and carrageenan gels using the "purge and trap" method, that the concentration of the aroma compound in the vapor phase decreased with the concentration of the thickener agent and with the increase in the viscosity of the medium.

The aim of this paper is to study the release of aroma compounds in a model food matrix containing $\beta$-lactoglobulin and oil in order to understand better the role of the composition and the structure of the medium (gel or emulsion).

\section{MATERIALS AND METHODS}

\subsection{Reagents}

\subsubsection{Aroma compounds}

The two aroma compounds, 2-nonanone and hex-4-en-3-ol, were kindly pro- vided by International Flavors and Fragrances (IFF, Longvic-lès-Dijon, France). These compounds were selected because of the differences in their physicochemical characteristics (Tab. I), particularly their differences in water solubility $(0.4$ and $18.0 \mathrm{~g} \cdot \mathrm{L}^{-1}$ at $25^{\circ} \mathrm{C}$, respectively) and the vapor-water partition coefficients $\left(\mathrm{K}_{\mathrm{mol}}\right)$ (33.6 and 0.5 at $25^{\circ} \mathrm{C}$, respectively).

\subsection{2. $\beta$-lactoglobulin}

It was provided by Besnier-Bridel (Laval, France). This industrial preparation was purified by solubilization $\left(20 \mathrm{~g} \cdot 100 \mathrm{~g}^{-1}\right)$ in an aqueous solution of $50 \mathrm{mmol} \cdot \mathrm{L}^{-1}$ $\mathrm{NaCl}$ and dialyzed over a $24 \mathrm{~h}$ period with a regenerated cellulose membrane (6000$8000 \mathrm{~g} \cdot \mathrm{mol}^{-1}$, Spectrapor, Medicell International Ltd, Liverpool, U.K.) with $\mathrm{NaCl}$ (20 times its volume). The protein solution had a concentration of around $120 \mathrm{~g} \cdot \mathrm{L}^{-1}$. This solution was diluted to $3 \%$ with $\mathrm{NaCl}$ solution. Aqueous protein solutions were adjusted to $\mathrm{pH} 3$ with $\mathrm{HCl}$ solution. 


\subsubsection{Miglyol}

It is a triglyceride of caprylic $(60 \%)$ and capric acid (40\%) with a density equal to 0.947 at $20^{\circ} \mathrm{C}$. This vegetable oil was provided by International Flavors and Fragrances (IFF, Longvic-lès-Dijon, France).

\subsubsection{Milk}

It contained $1.5 \%$ lipids and $4 \%$ proteins (half skimmed milk, commercial U.H.T. product).

\subsection{Preparation of emulsions and gels}

\subsubsection{Emulsions}

Miglyol was added to the aqueous protein phase. This medium was homogenized with an Ultra Turrax ${ }^{\circledR}$ T25 (Janke \& Kunkel, IKA Labortechnik, Staufen, Germany) for 10 min with a rotation speed of $24000 \mathrm{rpm}$ which permitted stable emulsions to be obtained. The aroma compounds were incorporated in the emulsion at a concentration of $100 \mathrm{ppm}$ and manually mixed. The preparations were realized in samples of $100 \mathrm{~mL}$ in $250 \mathrm{~mL}$ glass flasks.

Two emulsions were prepared:

- emulsion A: 5.0\% Miglyol, 6.9\% $\beta$-lactoglobulin, $\mathrm{pH} 3$;

- emulsion B: $1.5 \%$ Miglyol, $4.0 \%$ $\beta$-lactoglobulin, $\mathrm{pH} 3$.

The stability of the emulsions was verified with the help of laser granulometry measurements, by the Malvern Mastersizer MSX14-DIF2001 (Malvern Instruments, Worcs, England).

\subsubsection{Gels}

The gelation of protein aqueous solutions (6.9\% w/w $\beta$-lactoglobulin) or emulsions $(5 \% \mathrm{w} / \mathrm{w}$ Miglyol and $6.9 \% \mathrm{w} / \mathrm{w} \beta$-lactoglobulin), previously aromatized (100 ppm), was realized by heating at $76.0 \pm 0.5{ }^{\circ} \mathrm{C}$ for $10 \mathrm{~min}$. The formed gels (or gelified emulsions) were cooled for $1 \mathrm{~h}$ in a bath at $20^{\circ} \mathrm{C}$.

The destructuration of the gel was done by stirring for $2 \mathrm{~h}$ at $400 \mathrm{rpm}$.

\subsection{Quantification of the released aroma compounds}

To quantify the release of the aroma compounds as a function of time, we chose to determine their remaining quantity in the liquid phase: this method proved to be more precise than the dosage of the aromas in the gaseous phase for the short times of experimentation. This method was validated with simultaneous measurements of the liquid and gaseous phases on model aroma solutions (2-nonanone at 10 and $300 \mathrm{ppm}$ ). The simultaneous measurement of the two phases, vapor and liquid, of the initial solutions and after a time $t$ were carried out on water and gels to realize a mass balance. The losses were evaluated at less than $10 \%$. In aqueous solutions we observed low variation coefficients at different times of experimentation (between 1 and 2.5\%), that showed a good repeatability. For more complex media (emulsion, gel and milk) the variation coefficients were less than $5 \%$. Therefore the extraction step of aroma compounds in an organic solvent from the different media was not necessary to determine the remaining quantity of aroma compounds. The release of aroma compounds was determined by direct injection (injection volume: $2 \mu \mathrm{L}$ ) of the "liquid" phases (water, gel, emulsion, gelified emulsion or milk), and by staying in the field of the infinite dilution. Each point on the curves in Figures 1-2 was an independent experiment. Each point constituted a new experiment.

\subsection{Chromatographic analysis conditions}

Quantitative analysis of the aroma compounds was done using a Chrompack $\mathrm{CP}$ 9000 chromatograph (Chrompack Co., Middelberg, The Netherlands). Parameters for the gas chromatographic analysis were as follows:

- Stainless-steel column (3 m length by $2.2 \mathrm{~mm}$ inner diameter) packed with Chromosorb W-AW, 100-120 mesh coated with $10 \%$ Carbowax $20 \mathrm{~mol} \cdot \mathrm{L}^{-1}$. 


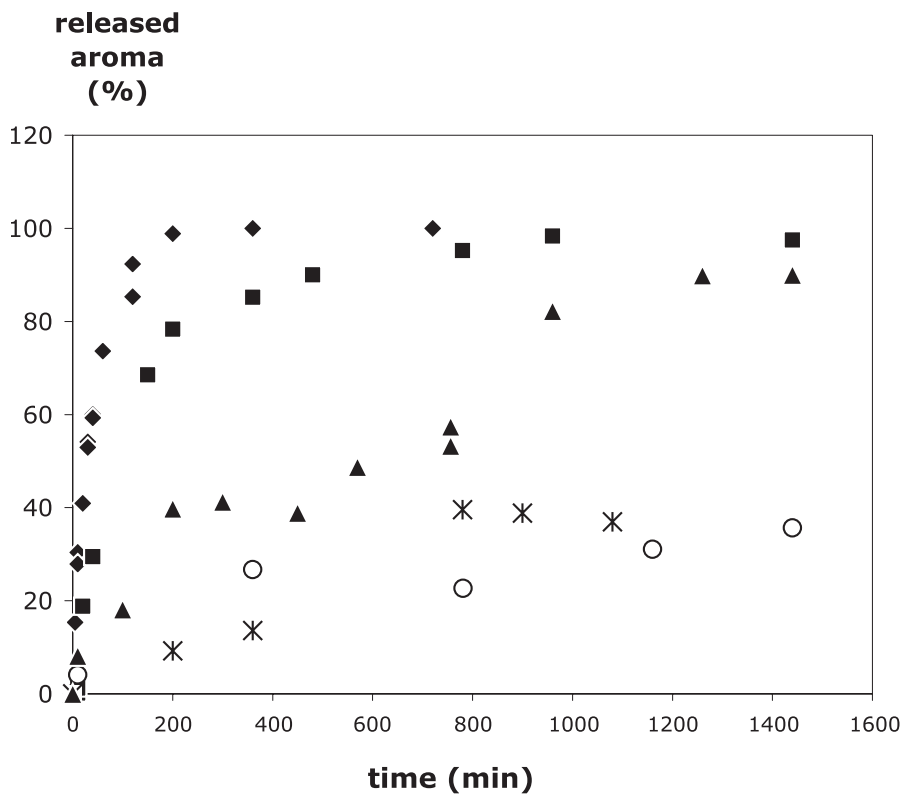

Figure 1. Release of 2-nonanone in different media (agitation $400 \mathrm{rpm}, 37^{\circ} \mathrm{C}$ ). $\downarrow$ water; $\mathbf{\square}$ gel; $\mathrm{O}$ emulsion; $*$ gelified emulsion; and $\boldsymbol{\Delta}$ milk.

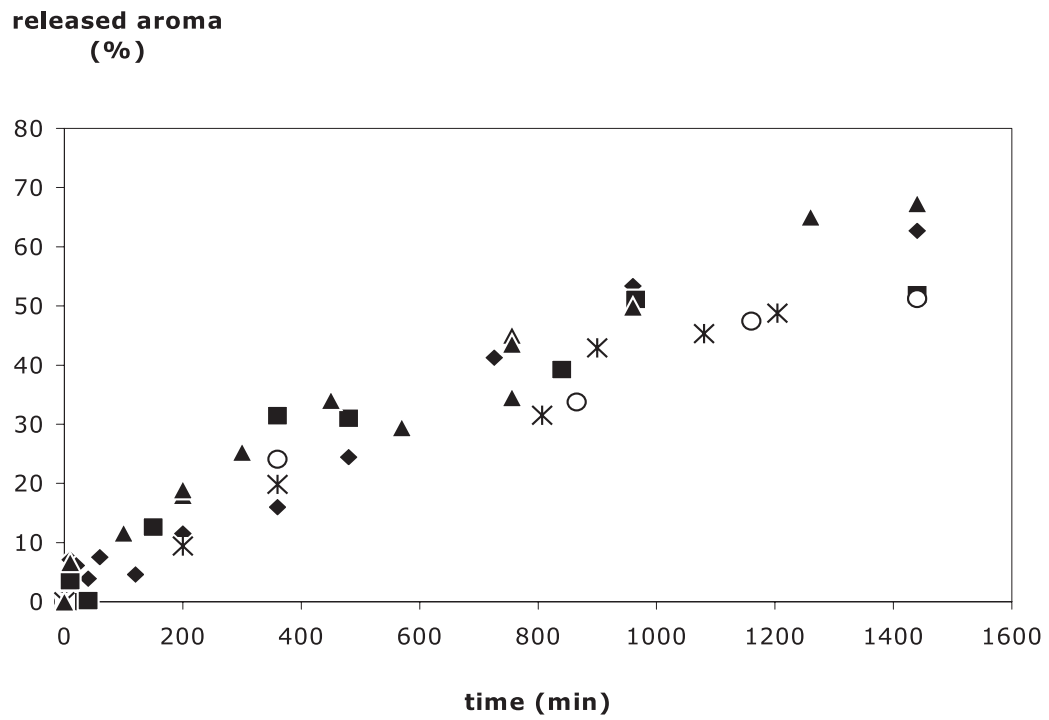

Figure 2. Release of hex-4-en-3-ol in different media (agitation $400 \mathrm{rpm}, 37^{\circ} \mathrm{C}$ ). $\mathrm{O}$ emulsion; $*$ gelified emulsion; and $\boldsymbol{\Delta}$ milk. 
Table II. Velocity constants release of the aroma compounds in different media compared with that in water (agitation $400 \mathrm{rpm}, 37^{\circ} \mathrm{C}$ ).

\begin{tabular}{lccccc}
\hline Media & $\begin{array}{c}\mathrm{v}_{(2-\text { nonanone })} \times \\
10^{5}\left(\mathrm{~min}^{-1}\right)\end{array}$ & $\begin{array}{c}\mathrm{v}_{(\text {hex-4-en-3-ol })} \times \\
10^{5}\left(\mathrm{~min}^{-1}\right)\end{array}$ & $\begin{array}{c}\mathrm{v}_{(\text {water })} / \mathrm{v}_{\text {(medium })} \\
\text { 2-nonanone }\end{array}$ & $\begin{array}{c}\mathrm{v}_{(2-\text { nonanone })} / \\
\text { hex-4-en-3-ol }\end{array}$ & $\mathrm{v}_{\text {(hex-4-en-3-ol })}$ \\
\hline Water & 1771 & 71 & 1.0 & 1.0 & 25 \\
Gel & 346 & 61 & 5.1 & 1.1 & 5.7 \\
Emulsion & 34 & 52 & 52.1 & 1.4 & 0.65 \\
Gelified & 52 & 55 & 34.1 & 1.3 & 0.95 \\
emulsion & & & & & \\
Milk & 156 & 77 & 11.4 & 0.9 & 2.0 \\
\hline
\end{tabular}

- Flow rates of carrier gas $\left(\mathrm{N}_{2}\right): 1.6 \times$ $10^{-5} \mathrm{~m}^{3} \cdot \mathrm{min}^{-1}$; hydrogen: $2.5 \times 10^{-5} \mathrm{~m}^{3} \cdot \mathrm{min}^{-1}$; and air: $25 \times 10^{-5} \mathrm{~m}^{3} \cdot \mathrm{min}^{-1}$.

- Flame ionization detector and injector temperatures were 200 and $190{ }^{\circ} \mathrm{C}$, respectively.

- Column temperature varied with the nature of the compounds (isotherms $100{ }^{\circ} \mathrm{C}$ and $140{ }^{\circ} \mathrm{C}$ for hex-4-en-3-ol and 2-nonanone, respectively).

- The chromatograms were registered and integrated with a Shimadzu CR6A integrator (Shimadzu Europa, Dursburg, Germany) connected to FID.

The calibration was realized by using 5 concentrations of each aroma compound $(20,50,100,200$ and $300 \mathrm{ppm})$ and replicating 4 times.

\subsection{Rheological method}

The rheological behavior was determined with a Rheomat 30 viscosimeter and a Reoscan 20 programmator (Contraves, Zurich, Switzerland) using a constant shearing speed equal to $44.9 \mathrm{~s}^{-1}$.

\section{RESULTS AND DISCUSSION}

The kinetics of release of 2-nonanone and hex-4-en-3-ol in different media are shown in Figures 1 and 2. The concentration of the released aroma (calculated by taking the difference of the initial and remaining quantities of aroma compounds in the liquid phase, and taking into account the losses) at the time $t$ is expressed as a percentage of the initial concentration of the volatile compound. The behavior of these two compounds was very different. The influence of the medium on the release of 2-nonanone is displayed (Fig. 1), whereas, the release curves with hex-4-en-3-ol indicated a similar behavior whatever the medium (Fig. 2). The influences of the medium and the nature of the aroma compound are discussed separately to explain these results.

\subsection{Influence of the medium on the release of aroma compounds}

The constants of the rate of release of 2nonanone in the different media were calculated considering a first order kinetic, according to the same assumption than that of Dickinson et al. [4] who worked on the release of butan-1-ol from aqueous medium and emulsion. These authors have shown that a model of the first order kinetic can be applied. Then the same kind of calculation was used and the percentage of the remaining aroma compounds in the medium was expressed from the equation:

$$
\% \text { remaining aroma }=100 \mathrm{e}^{-\mathrm{vt}}
$$

where 100 corresponds to the initial percentage of aroma in the medium; $\mathrm{v}$, the speed constant $\left(\mathrm{min}^{-1}\right)$; and $\mathrm{t}$, time $(\mathrm{min})$. 


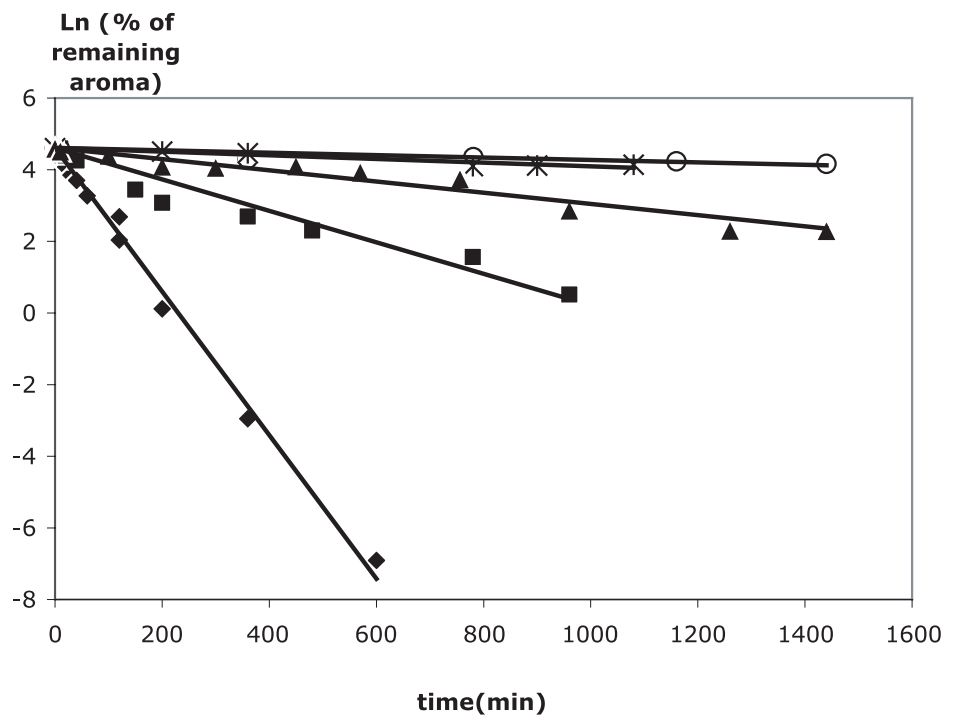

Figure 3. Release of 2-nonanone: remaining aroma in the media using a kinetic of the first order. $\checkmark$ water; gel; $\mathrm{O}$ emulsion; $*$ gelified emulsion; and $\boldsymbol{\Delta}$ milk.

The drawing of graphs of the Log of the percentage of the aroma remaining in the media (water, gel, emulsion, gelified emulsion and milk) as a function of time (Fig. 3) allowed us to determine the speed constants with the help of the slope of each curve. These constants are presented in Table II. The release in water was quicker compared with those in the other media (gel, emulsion, gelified emulsion and milk). The ratio $\mathrm{v}_{\text {water }} / \mathrm{v}_{\text {media }}$ indicated the decrease factor of the release in the different media. The speed constant of 2-nonanone is 5 times weaker in the gel compared with those determined in water. This difference can be explained by the presence of interactions of the methylketone with the protein. Espinosa Diaz [6] has observed a volatility decrease of $57 \%$ of this compound (initial concentration $100 \mathrm{ppm}$ ) in the presence of $3 \% \beta$ lactoglobulin aqueous solutions at $\mathrm{pH} 3$. Moreover, the diffusion coefficient of 2nonanone decreased in the presence of this protein at $\mathrm{pH} 3$ compared with that in water $\left(9.3 \times 10^{-10} \mathrm{~m}^{2} \cdot \mathrm{s}^{-1}\right.$ in water and $7.0 \times$ $10^{-10} \mathrm{~m}^{2} \cdot \mathrm{s}^{-1}$ in $\beta$-lactoglobulin aqueous solution) [6]. Hence, the kinetics of this compound were influenced by the presence of the protein in the medium.

The rheological measurements indicated a shearing strength of the gel equal to $29 \mathrm{mPa} \cdot \mathrm{s}$ (measured at $37^{\circ} \mathrm{C}$ with $2 \%$ of variation coefficient) and that of water of around $1 \mathrm{mPa} \cdot \mathrm{s}$. Certainly the network of the gel constituted by $\beta$-lactoglobulin played an important role in the release of 2-nonanone. But the nature of the volatile was also important. The behavior of hex-4-en-3-ol was very different to that of 2-nonanone. In the case of hex-4-en-3-ol, the differences of release in water and in gelified media were small (speed constants of hex-4-en-3ol were $71 \times 10^{-5}$ and $61 \times 10^{-5} \mathrm{~min}^{-1}$ in water and in gel, respectively). These results are in agreement with those of Roberts et al. [25] who have pointed out that, besides the effects of the nature of the thickener agents (saccharose, carboxymethylcellulose or guar gum) and that of the nature of aroma compounds, the viscosity of the medium influenced the release of flavor compounds. In the present study, a lower release speed in gel compared with 
Table III. Released aroma (\%) in gel and destructured gel compared with water.

\begin{tabular}{lccc}
\hline Medium & Water & Gel & Destructured gel \\
\hline Released aroma $(\%)$ & $98.9 \pm 1.0$ & $78.3 \pm 2.0$ & $83.5 \pm 2.1$ \\
\hline
\end{tabular}

water was expected because of the effect of a higher viscosity of the gel.

The decrease in the speed constants in the gel $(80 \%$ for 2 -nonanone and $15 \%$ for hexenol) could be due to the fact that the aroma compound was trapped in the protein net and that the transfer was partially hindered by it. A destructuration of the gel would be necessary to allow its release. To study the effect of the destructuration of the gelified medium, we compared the percentage after $200 \mathrm{~min}$ of 2-nonanone release in a gel with that of another gel (same composition) which had been stirred for $2 \mathrm{~h}$ at $400 \mathrm{rpm}$ (Tab. III). On comparison of the two gels (with and without destructuration) it was shown that there was a slightly, but significantly higher quantity of aroma compound release in the destructured gel $(83.5 \pm 2.1 \%$ and $78.3 \pm$ $2.0 \%$ released aroma in gels with and without destructuration, respectively). The difference in release could be due to the structure changes. The shearing strength of the destructurated gel (after $2 \mathrm{~h}$ of agitation at $400 \mathrm{rpm}$ ) was $21 \mathrm{mPa} \cdot \mathrm{s}$ compared with that before stirring equal to $29 \mathrm{mPa} \cdot \mathrm{s}$ (variation coefficient: $2 \%$ ). Smaller particles were obtained, the surface area for flavor release was probably changed and the structure on a small scale (interactions) was modified.

\subsection{Emulsified media}

A slightly slower release of 2-nonanone at equilibrium was observed in the liquid emulsion compared with the gelified emulsion (speed constants were $34 \times 10^{-5}$ and $52 \times 10^{-5} \mathrm{~min}^{-1}$, respectively) while this tendency seemed to be the inverse during the 400 first min. The gelified medium was more structured than the liquid emulsion.
However, Espinosa Diaz [6] showed that in the aqueous media the affinity of 2-nonanone for the medium played an important role in its release and the conformation of the protein influenced its affinity.

The gelified emulsion was produced by heating the emulsion at $76^{\circ} \mathrm{C}$ for $10 \mathrm{~min}$. These conditions did not allow us to obtain a hard gel but they induced changes in the conformation of $\beta$-lactoglobulin [21]. By heating, a $\beta$ structure inside the $\beta$-lactoglobulin protein unpleated was modified: a rearrangement in hazard rolled structures followed. This modification (unpleating) allowed the exhibition of the hydrophobic lateral chains that became disposable for the formation of molecular association [21]. These structural transformations of the protein were able to modify its affinity for the aroma compound. These results are in agreement with the study of O'Neill and Kinsella [22] who have shown a decrease of retention of 2-nonanone when the $\beta$-lactoglobulin was heated to $75{ }^{\circ} \mathrm{C}$ for 10 or $20 \mathrm{~min}$. The decrease was higher with the increase in heating time. McNulty and Karel [19] explained that the release of the aroma compounds in emulsified media happens in two steps: a transfer from the lipidic to the aqueous phase (particularly for the apolar compounds), followed by a release in the vapor phase. The transfer from Miglyol to water must be considered, especially in the presence of protein. Rogacheva et al. [26] observed, with the use of a rotating diffusion cell, an increase in the resistance of transfer of 2-nonanone at the Miglyol-water interface with the presence of $\beta$-lactoglobulin in the aqueous phase at $\mathrm{pH} 3$. They have also shown the effect of the conformation of the protein on the transfer resistance of 2-nonanone: at $\mathrm{pH} 9$, the interfacial transfer resistance was 
weaker than that observed at $\mathrm{pH} 3$, because of a more uniform interfacial $\beta$-lactoglobulin layer between Miglyol and water. In fact, the $\beta$-lactoglobulin is partially denatured in alkaline conditions [2]. Likewise, at $\mathrm{pH}$ $3 \beta$-lactoglobulin is relatively resistant to heating, and this treatment induced only a partial denaturation. Heat treatment (from 60 to $130{ }^{\circ} \mathrm{C}$ ) of $\beta$-lactoglobulin in solution at $\mathrm{pH} 2.5$ produced at least two molecular species, one native-like and indistinguishable from the native state by several criteria of characterization (solubility in varied ionic conditions, electrophoresis, gel permeation chromatography) and the other a product of an irreversible change [10].

We admit that the heating of the emulsion to induce the gelation modifies the characteristics of the interfacial protein layer. Thus the release velocity could be higher in the gelified emulsion compared with the non-gelified emulsion, due to a thinner protein layer when the $\beta$-lactoglobulin is denatured by heating. The resistance to the transfer at the Miglyol-water interface would be weaker because protein-protein interactions are more numerous in gel and decrease in hydrophobic areas. The experimental data showed few differences between the two emulsions (gelified or not). With these weak values of slopes (Tab. II), the assumption of a first order kinetic doubtless was in limit of applicability and the observed differences showed only a tendency but not a significant difference.

For milk, the velocity release constant of 2-nonanone $\left(156 \times 10^{-5} \mathrm{~min}^{-1}\right)$ was around 5 times higher compared with that of the $\beta$-lactoglobulin emulsion $\left(34 \times 10^{-5} \mathrm{~min}^{-1}\right)$. These two media had different compositions and a different structure of proteins. The bovine milk contains $3.0-3.4 \%$ (w/v) protein, less than the $\beta$-lactoglobulin suspension studied in this paper $(6.9 \% \mathrm{w} / \mathrm{v})$. Moreover, the milk proteins are composed of $75 \%(\mathrm{w} / \mathrm{w})$ of a supramolecular edifice, the casein micelles, and of $12 \%$ of $\beta$-lactoglobulin. The structure of $\beta$-lactoglobulin was totally different to that of the casein micelles.
The milk contains $1.5 \%$ lipids with more than two hundred different triacylglycerols, whereas Miglyol is a simple lipid containing only $\mathrm{C}_{8: 0}$ and $\mathrm{C}_{10: 0}$ residues. To compare with identical proportions of the constituent family, another emulsion was realized containing the same proportions of lipid and protein as milk. The percentage of 2nonanone remaining after $13 \mathrm{~h}$ of the experiment was $44.7 \pm 3.0 \%$ and $37.4 \pm 5.0 \%$ in milk and in this new $\beta$-lactoglobulin emulsion, respectively. These values were not significantly different.

\subsection{Comparison between aqueous and emulsified media}

The behavior of 2-nonanone was strongly influenced by the presence of lipid in the food matrix. The volatility of this aroma compound decreased by $80 \%$ in the presence of $0.5 \%$ Miglyol. The lipid also had an effect on its kinetic release: the velocity constant was 52 times higher in water than in the emulsion. Also, the release was 7 times quicker from the fat-free gel than from the gelified emulsion. The effect of Miglyol could be explained by the high affinity of this aroma compound for the lipid and by an increase in the medium viscosity. The influence of the lipids on the release of aroma compounds in complex foods was observed by Ingham et al. [11].

The behavior of hex-4-en-3-ol was very different of that of 2-nonanone. For hex-4en-3-ol, the value of the ratio of the velocity constants between water and all the other media was around 1. This is especially true in the case of milk, where this ratio is equal to 0.9 (Tab. II). This is in agreement with the results of De Roos and Wolswinkel [3] who calculated a correction factor to obtain the same flavor intensity of hex-4-en-3-ol in water and in milk to be equal to 1 . Thus the sensorial behavior was found to be the same in these two media for hex-4-en-3-ol. The behavior of 2-nonanone was very much different and showed a higher ratio for emulsions (gelified or not). 


\subsection{Influence of the nature of the aroma compound on its release}

To quantify the differences in the kinetic release of 2-nonanone and hex-4-en-3-ol (Figs. 1 and 2), the ratio of their velocity coefficients $\left(\mathrm{v}_{(2-\text {-nonanone }) /} \mathrm{V}_{(\text {hex-4-en-3-ol }}\right)$ was calculated for each media (Tab. II). The greatest difference was observed when the compounds were introduced into water: the velocity coefficient of 2-nonanone was 25 times higher than that of hex-4-en-3-ol. This observation could be explained by the physicochemical characteristics of the 2 aroma compounds: the vapor-liquid partition coefficients of 2-nonanone and hex-4en-3-ol in water at $25^{\circ} \mathrm{C}$ are 33.6 and 0.5 (in molar fractions), respectively. The higher solubility of hex-4-en-3-ol in water $\left(18 \mathrm{~g} \cdot \mathrm{L}^{-1}\right)$ also explained its higher retention in the aqueous media. For the gel, the behavior differences of the aroma compounds were less significant than in water but remained higher; however, the velocity coefficient of 2-nonanone was more than 5 times higher than that of hex-4-en-3-ol. The affinity of 2-nonanone for the $\beta$-lactoglobulin network increased its retention. When the medium contained lipids, the behavior differences were less significant, and the ratio became closer to 1 . When the lipid content varied, the opposite effect was observed. In milk, with $1.5 \%$ lipids, the release of 2-nonanone was higher than that of hex-4-en-3-ol. At a higher lipid content (5\% Miglyol) the release of 2-nonanone was lower (for gelified and non-gelified emulsion).

The comparison between the two aroma compounds showed the strong influence of the compound nature on the release because the interactions with the food matrix are very different, probably because the binding mechanisms on the protein of these two compounds are different and perhaps they do not have the same binding site, in the hydrophobic pocket and on an external site of the protein.

\section{CONCLUSION}

The release of 2-nonanone and hex-4en-3-ol in different media, in similar conditions of agitation and temperature, depended principally on the nature of the compound and the composition of the medium, because of the solute-food matrix interactions. The studied media were water, a gel of $\beta$-lactoglobulin, gelified or non-gelified emulsions containing Miglyol added to an aqueous protein phase, and milk. A strong influence of the nature of the aroma compound on its behavior towards the matrix was pointed out; for 2-nonanone, a hydrophobic compound $(\log \mathrm{P}=2.9)$ and relatively volatile in water $\left(\mathrm{K}_{\mathrm{mol}}=33.6\right)$, the profile release was influenced by the composition and the structure of the medium. For hexenol, a more hydrophilic compound $(\log \mathrm{P}=1.7)$ and less volatile $\left(\mathrm{K}_{\mathrm{mol}}=0.5\right)$, the kinetic of release was modified neither by the composition of the food matrix nor its structure. The differences in behavior of these two compounds showed that the aroma release was principally influenced by the interactions with the non-volatile constituents, $\beta$-lactoglobulin and Miglyol. An effect of the mesostructure such as gelling also occurred, inducing a decrease in release velocity. The destructuration of gelified emulsions (or fat-free gels) led to a suppression in organization (and perhaps a hydrophobic cavity) and hence to an increase in release. In the case of emulsions, the structure of the oil-water interface made with $\beta$-lactoglobulin also seemed to have an effect on the kinetic release of 2-nonanone, the compound having a strong affinity for the lipid. Since heating is often required at some stage of the product processing, these observations may be taken into account in industrial aromatized food products (containing $\beta$-lactoglobulin) where gelation occurs, and indicate the role of $\beta$-lactoglobulin in the release of volatile compounds of different natures.

Acknowledgments: M. Espinosa Diaz gratefully acknowledges financial support from the 
Ministère de l'Éducation et de la Recherche, France, and CONACYT, Mexico.

\section{REFERENCES}

[1] Agboola S.O., Dalgleish D.G., Calciuminduced destabilization of oil-in-water emulsions stabilized by caseinate or $\beta$-lactoglobulin, J. Food Sci. 60 (1995) 399-404.

[2] Casal H.L., Köhler U., Mantsch H.H., Structural and conformational changes of $\beta$-lactoglobulin B: an infrared spectroscopic study of the effect of $\mathrm{pH}$ and temperature, Biochim. Biophys. Acta 957 (1988) 11-20.

[3] De Roos K.B., Wolswinkel K., Non-equilibrium partition model for predicting flavor release in the mouth, Dev. Food Sci. 35 (1994) 15-32.

[4] Dickinson E., Evison J., Gramshaw J.W., Schwope D., Flavor release from a proteinstabilized water-in-oil in water emulsion, Food Hydrocoll. 8 (1994) 63-67.

[5] Durand D., Gimel J.C., Nicolai T., Aggregation, gelation and phase separation of heat denatured globular protein, Physica A 304 (2002) 253-265.

[6] Espinosa Diaz M.A., Study of the retention and release of aroma compounds in model media in the presence or in absence of $\beta$-lactoglobulin, Ph.D. Dissertation, Université de Bourgogne, France, 1999.

[7] Espinosa Diaz M.A., Guetachew T., Landy P., José J., Voilley A., Experimental and estimated saturated vapour pressures of aroma compounds, Fluid Phase Equilibria 157 (1999) 257-270.

[8] Furia T.E., Bellanca N., Fenaroli's Handbook of Flavor Ingredients, 2nd edn., vol. 2, CRC Press, Cleveland, Ohio, USA, 1975.

[9] Guichard E., Interactions between flavor compounds and food ingredients and their influence on flavor perception, Food Rev. Int. 18 (2002) 49-70.

[10] Harwalkar V.R., Kalab M., Denaturation and aggregation of $\beta$-lactoglobulin in solution. Electron microscopy study, Milchwissenschaft 40 (1985) 65-68.

[11] Ingham K.E., Taylor A.J., Chevance F.F.V., Farmer L.J., Effect of fat content on volatile release from foods, in: Taylor A.J., Mottram D.S. (Eds.), Flavour science. Recent developments, The Royal Society of Chemistry, Cambridge, U.K., 1996, pp. 386-391.

[12] Jameson G.B., Adams J.J., Creamer L.K., Flexibility, functionality and hydrophobicity of bovine $\beta$-lactoglobulin, Int. Dairy J. 12 (2002) 319-329.
[13] Jouenne E., Crouzet J., Effect of $\mathrm{pH}$ on retention of aroma compounds by $\beta$-lactoglobulin, J. Agric. Food Chem. 48 (2000) 1273-1277.

[14] Kinsella J.E., Milk proteins: physicochemical and functional properties, CRC C. R. Food Sci. Nutr. (1984) 197-262.

[15] Langton M., Hermansson A.M., Finestarnded and particulate gels of $\beta$-lactoglobulin and whey protein at varying $\mathrm{pH}$, Food Hydrocoll. 5 (1992) 523-539.

[16] Lundgren B., Pangborn R.M., Daget N., Yoshida M., Laing D.G., Mc Bride R.L., Griffiths N., Hyvonen L., Sauvageot F., Paulus K., Pikielna N.A., An interlaboratory study of firmness, aroma, and taste of pectin gels, Lebensm. -Wiss. u.- Technol. 9 (1986) 66-76.

[17] Matsumodi N., Rector D., Kinsella J.E., Gelation of bovine serum albumine and $\beta$ lactoglobulin: effects of $\mathrm{pH}$, salts and thiol reagents, Food Chem. 40 (1991) 55-69.

[18] McClements J.D., Monahan F.J., Kinsella T.E., Disulfide bond formation affects stability of whey protein isolate emulsions, J. Food Sci. 58 (1993) 1036-1039.

[19] McNulty P.B., Karel M., Factors affecting flavour release and uptake in o/w emulsions. I. Release and uptake models, J. Food Technol. 8 (1973) 309-318.

[20] Mills O.E., Solms J., Interaction of selected flavour compounds with whey proteins, Lebensm. -Wiss. u.- Technol. 17 (1984) 331-335.

[21] Mulvihill D.M., Donovan M., Whey proteins and their thermal denaturation. A review, Ir. J. Food Sci. Technol. 11 (1987) 43-75.

[22] O'Neill T.E., Kinsella J.E., Effect of heat treatment and modification on conformation and flavor binding by $\beta$-lactoglobulin, $\mathrm{J}$. Food Sci. 53 (1988) 906-909.

[23] Rankin S.A., Bodyfelt F.W., Headspace diacetyl as affected by stabilizers and emulsifiers in a model dairy system, J. Food Sci. 61 (1996) 921-923.

[24] Reiners J., Nicklaus S., Guichard E., Interactions between $\beta$-lactoglobulin and flavour compounds of different classes. Impact of the protein on the odour perception of vanillin and eugenol, Lait 80 (2000) 347-360.

[25] Roberts D.D., Elmore J.S., Langley K.R., Bakker J., Effects of sucrose, guar gum, and carboxymethylcellulose on the release of volatile flavor compounds under dynamic conditions, J. Agric. Food Chem. 44 (1996) 1321-1326.

[26] Rogacheva S., Espinosa Diaz M.A., Voilley A., Transfer of aroma compounds in water-lipids 
systems: binding tendency of $\beta$-lactoglobulin, J. Agric. Food Chem. 47 (1999) 259-263.

[27] Shimizu M., Structure of proteins adsorbed at an emulsified oil surface, in: Dickinson E., Lorient D. (Eds.), Food Macromolecules and Colloids, the Royal Society of Chemistry, Cambridge, U.K., 1995, pp. 34-42.

[28] Van Ruth S.M., Villeneuve E., Influence of $\beta$-lactoglobulin, $\mathrm{pH}$ and presence of other aroma compounds on the air/liquid partition coefficients of 20 aroma compounds varying in functional group and chain length, Food Chem. 79 (2002) 157-164.

[29] Walstra P., de Roos A.L., Proteins at airwater and oil-water interfaces: static and dynamic aspects, Food Rev. Int. 9 (1993) 503-525.

[30] Wilson C.E., Brown W.E., Influence of food matrix structure and oral breakdown during mastication on temporal perception of flavor, J. Sens. Stud. 21 (1997) 69-86. 